\title{
Correlation between prenatal exposures of lead with child development: a meta-analysis
}

\author{
Rayi Kurnia Perwitasaria, ${ }^{a, b}$, Irwanto $^{a, b}$, and Indri Safitric \\ ${ }^{a}$ Department of Pediatrics, Faculty of Medicine Universitas Airlangga 60132, Surabaya, East Java, Indonesia \\ ${ }^{\mathrm{b}}$ Dr. Soetomo General Hospital, 60286, Surabaya, East Java, Indonesia \\ ${ }^{c}$ Department of Biochemistry, Faculty of Medicine Universitas Airlangga 60115. Surabaya, East Java, Indonesia \\ *Email: rayi.kurnia.p@gmail.com
}

\begin{abstract}
Heavy metals globally are known to become major factors to cause birth abnormal. Some elements, such as lead $(\mathrm{Pb})$, mercury $(\mathrm{Hg})$, cadmium $(\mathrm{Cd})$, arsenic (As), and chromium $(\mathrm{Cr})$, can move across the placental barrier and the blood-brain barrier, causing neurotoxicity in the fetus. These neurotoxicity effects can lead to congenital and neurological disabilities, developmental delays, behavioral disorders, and learning disabilities through several mechanisms. This systematic review study and meta-analysis used secondary data from articles taken from 2001 to 2020 through the PubMed database, Google Scholar. There were 4 articles for lead that matched the inclusion and exclusion criteria. Analysis using the Revman Review Manager 5.4. The results showed that comparing the lead exposure to The Wechsler Intelligence Scale for Children (WISC) score, the effect of magnitude combination was -2.00 (95\% CI $-3.79 ;-0.21), p=0.03$ on cognitive development. From this study, it was found that there was an association between prenatal lead exposure and child development.
\end{abstract}

Keywords: Lead; heavy metals; child development; meta-analysis

\section{Introduction}

Heavy metal is a group of metals correlated by contamination and potentially toxic or eco-toxic. Heavy metal is categorized based on density, which is a less significant biological property. Material is classified as heavy metal if the density value is more than 4 grams $/ \mathrm{cm}^{3}$ (Duffus, 2002). Some metals such as zinc, copper, iron, manganese, and cobalt are needed by the human body but can be toxic if consumed in high concentrations. Some heavy metals, such as lead, are not yet known to have beneficial effects on humans, even harmful to health if they accumulate in the body for a certain period (Rehman et al., 2018). Heavy metals, especially lead $(\mathrm{Pb})$, mercury $(\mathrm{Hg})$, cadmium $(\mathrm{Cd})$, arsenic $(\mathrm{As})$, and chromium $(\mathrm{Cr})$, are known to cause birth abnormalities. These materials are abundant in the environment, either natural or anthropogenic. Exposure can occur prenatally or postnatally. Exposure to heavy metals can be through food, inhalation, and handling of chemical and industrial contaminants (Caserta et al., 2013). Neurotoxicity effects due to heavy metal exposure are known to cause congenital and neurological defects, developmental delays, behavioral disorders, and learning disabilities through several mechanisms, including the formation of oxidative stress that can inhibit the development of dendritic and synaptic neurons, inhibit neuronal signaling pathways and alter brain neurochemistry (Hsueh et al., 2017).

Early identification of developmental disorders is an integral function of essential consideration and the 
responsibility of all child medical services experts. The American Academy of Pediatrics (AAP) suggests developmental and behavioral screening for all infants through frequent visits for healthy infants at nine months, 18 months, 24, or 30 months. The Indonesian Pediatrician Association (IDAI) recommends that the process of child growth and development during the critical first three years of life must be sufficiently monitored and recorded. Wechsler defines intelligence as the general capacity of an individual to act fully with a specific purpose, to think and do something about the environment. Wechsler Intelligence Scales used there are three, namely Wechsler Adult Intelligence Scale (WAIS), Wechsler Intelligence Scale for Children (WISC), and Wechsler Preschool and Primary Scale of Intelligence (WPPSI) (Sternberg, 2000).

Therefore, this systematic review meta-analysis study was initiated to study the consistency of the results of studies that have been carried out regarding the correlation between prenatal lead exposures to child development. Identifying the relationship is expected to be an additional reference that examines prenatal lead effect on child development.

\section{Material and Methods}

In this study, the research questions used PICO (Population, Intervention/Issue, Comparison/Context, and Outcome). Research literature through free search or electronic databases. The electronic database in this research literature search used PubMed and Google Scholar to identify relevant research. In this step searching for keywords (search terms) using Boolean Operators (Search Commands) include: AND / OR / NOT. The keywords (search terms) used were "prenatal lead" OR "blood cord lead" AND "developmental delay". The inclusion criteria in this research were journals published between 2000-2020, derived from the PubMed and Medline databases, research subjects are pediatric patients up to the age of 18 years, a prospective cohort study with prenatal lead exposure studies can be in the form of maternal urine lead during pregnancy, maternal blood in pregnancy, or umbilical cord blood during delivery using the developmental examination instrument The Wechsler Intelligence Scale for Children (WISC), and journal articles contain beta values and standard errors, or beta values and confidence intervals. The exclusion criteria were case-study articles or case series, subject study designs in the form of experimental animals, literature reviews, and those that only evaluate indirect lead exposure through questionnaires, or postnatal lead exposure, and incomplete journal data, not open access journal, journal in abstract form. The collected data is managed according to the preferred reporting items for systematic review and meta-analysis (PRISMA). All articles collected are identified, screened, eligible, and include to determine the articles to be analyzed. In assessing the quality of research and journal feasibility, there are several criteria used to evaluate the research results and the journals used. The checklist in Strengthening the Reporting of Observational Studies in Epidemiology (STROBE) was used to evaluate the methodological quality of the study.

In data preparation, the important information is transferred from the selected literature into certain forms/tables to make it easier for researchers to identify the literature. In this study, a modified data collection form from Cochrane (The Cochrane Library) was used. This data collection form from Cochrane contains the identity, characteristics, methods, and results of the research specifically to make it easier for researchers to analyze the literature reviewed and then presented in tabular form to make it easier for researchers to analyze the characteristics of the research being reviewed. The data that has been collected is analyzed using metaanalysis, which is a combination of statistical research results from two or more separate and similar studies, to answer research questions. The Meta-Analysis process includes calculating the treatment effect (using the mean difference or beta value) and the confidence interval in each study, calculating the overall treatment effect as a summary of the results of the analysis. The Meta-Analysis process is carried out using the Revman Review 
Manager 5.4 software (Shaikh et al., 2021). The results of the meta-analysis are described and explained in the form of forest plots and narratives to facilitate understanding and provide clearer conclusions to readers on the results of the research and synthesis of the articles reviewed, and funnel plots to see any publication bias.

\section{Results}

There were 4 studies selected from the screening of titles related to the development of lead. The determination of the selected research criteria is based on the availability of data and the validity of the measurement method. Exposure is measured by determining prenatal exposure, namely maternal hair during pregnancy, maternal blood during pregnancy, or umbilical cord blood during delivery. The following is the PRISMA flow diagram in Figure 1.

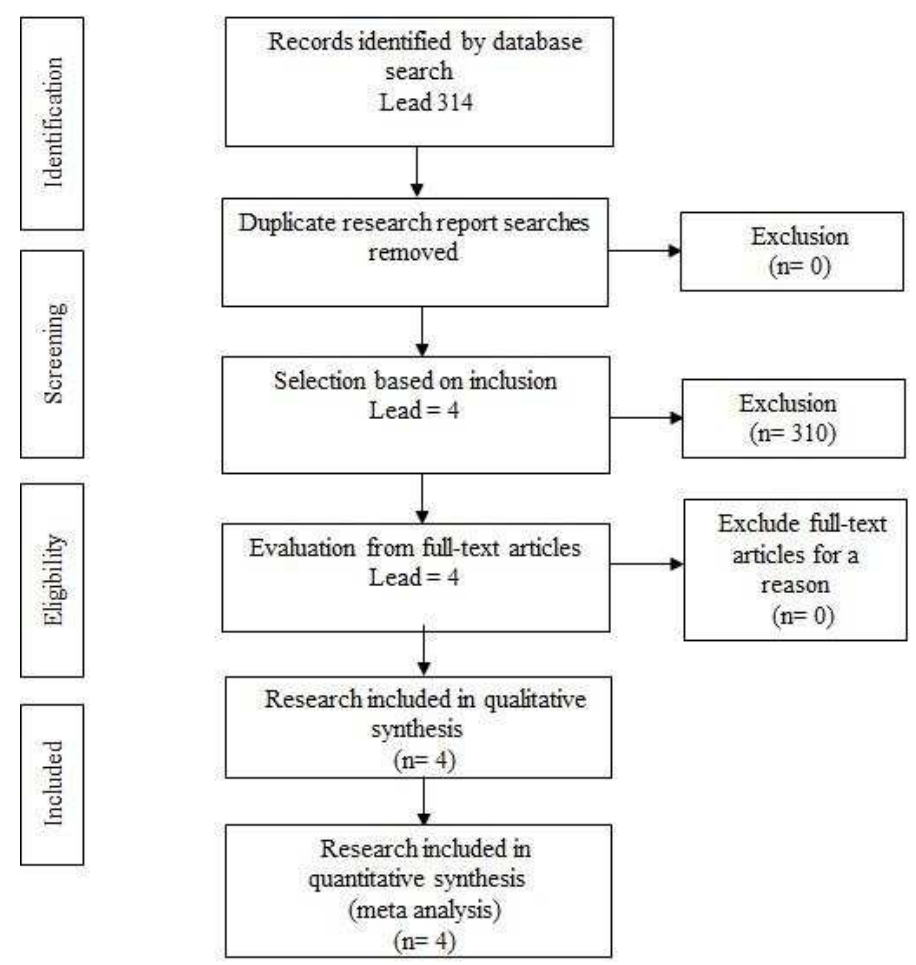

Fig. 1. PRISMA flow chart

The main instrument used to evaluate prenatal lead exposure on child development is the various versions of the Wechsler intelligence scale (WISC-III, WISC-IV, WISC-R, WISC-RM, WPPSI-III, WPPSI-R) for children aged between 5 years and 15. This type of test is used in all articles evaluating the effect of this metallic element on the neurodevelopment of children. All studies included in the review were of high methodological quality based on the checklist on Strengthening the Reporting of Observational Studies in Epidemiology (STROBE) 
shown in Table 1.

Table 1. Assessment of article's quality

\begin{tabular}{|c|c|c|c|c|c|c|c|c|c|c|}
\hline Title & $\begin{array}{c}\text { Stud } \\
\mathbf{y} \\
\text { desig } \\
\mathbf{n}\end{array}$ & $\begin{array}{c}\text { Settin } \\
\mathrm{g}\end{array}$ & $\begin{array}{c}\text { Participan } \\
\text { ts }\end{array}$ & $\begin{array}{c}\text { Variabl } \\
\text { es }\end{array}$ & $\begin{array}{c}\text { Data } \\
\text { Sources/Measurem } \\
\text { ent }\end{array}$ & $\begin{array}{c}\text { Bia } \\
\mathrm{s}\end{array}$ & $\begin{array}{c}\text { Stud } \\
\mathbf{y} \\
\text { Size }\end{array}$ & $\begin{array}{c}\text { Quantitati } \\
\text { ve } \\
\text { Variables }\end{array}$ & $\begin{array}{c}\text { Statistic } \\
\text { al } \\
\text { Method }\end{array}$ & $\begin{array}{c}\text { Scor } \\
\text { e }\end{array}$ \\
\hline $\begin{array}{l}\text { Caroline } \\
\text { Taylor et } \\
\text { al, } 2017\end{array}$ & + & + & + & + & + & + & + & + & + & 9 \\
\hline
\end{tabular}

Data extraction was carried out using a modified data collection form from Shaikh. The data that the researcher collected from the articles included: author, article title, research location, research sample, study design, heavy metal content, developmental tests, and results shown in Table 2.

\begin{tabular}{|c|c|c|c|c|c|c|c|}
\hline No & Journal title/number & $\begin{array}{l}\text { Author, } \\
\text { year, } \\
\text { country }\end{array}$ & $\begin{array}{l}\text { Number } \\
\text { of } \\
\text { samples }\end{array}$ & $\begin{array}{l}\text { Research } \\
\text { methods }\end{array}$ & $\begin{array}{c}\text { Exposure } \\
\text { assessment/instrume } \\
\text { nt }\end{array}$ & $\begin{array}{l}\text { Confoundin } \\
\text { g factor }\end{array}$ & Results \\
\hline 1 & $\begin{array}{l}\text { PMID: } 11120386 \text { DOI: } \\
\text { 10.1016/s0892- } \\
0362(00) 00106-9\end{array}$ & $\begin{array}{l}\text { G. A } \\
\text { Wasserman } \\
\text { et al, 2000 } \\
\text { Yugoslavia } \\
\text { The } \\
\text { Yugoslavia } \\
\text { Prospective } \\
\text { Lead Study: } \\
\text { contributions } \\
\text { of prenatal } \\
\text { and postnatal } \\
\text { lead } \\
\text { exposure to } \\
\text { early } \\
\text { intelligence }\end{array}$ & $\begin{array}{l}\text { Of the } \\
1167 \\
\text { mother- } \\
\text { child } \\
\text { cohorts, } \\
\text { only } 390 \\
\text { children } \\
\text { were } \\
\text { tested for } \\
\text { intelligenc } \\
\text { e at } \\
3,4,5,7 \\
\text { months of } \\
\text { age. }\end{array}$ & $\begin{array}{l}\text { Prospectiv } \\
\text { e cohort }\end{array}$ & $\begin{array}{c}\text { Prenatal lead } \\
\text { exposure is taken } \\
\text { from the mother's } \\
\text { blood during mid- } \\
\text { pregnancy } \\
\text { For children aged } 3 \\
\text { and } 4 \text { months, } \\
\text { intelligence } \\
\text { assessment uses the } \\
\text { McCarthy Scales of } \\
\text { Children's Abilities } \\
\text { (MSCA). In children } \\
\text { aged 5 and } 7 \text { months, } \\
\text { intelligence testing } \\
\text { using Full-scale IQ } \\
\text { (FSIQ) WPPSI-R } \\
\text { (The Wechsler } \\
\text { Preschool and } \\
\text { Primary Scale of } \\
\text { Intelligence-Revised) } \\
\text { and WISC-III (The } \\
\text { Wechsler Intelligence } \\
\text { Scale for Children- } \\
\text { version III) }\end{array}$ & $\begin{array}{l}\text { Child's } \\
\text { gender, birth } \\
\text { weight, } \\
\text { ethnicity, } \\
\text { maternal age, } \\
\text { mother's } \\
\text { education } \\
\text { level, } \\
\text { number of } \\
\text { previous live } \\
\text { births }\end{array}$ & $\begin{array}{l}\text { Prenatal lead } \\
\text { levels are } \\
\text { associated } \\
\text { with a slight } \\
\text { decrease in } \\
\text { intelligence } \\
\text { after } \\
\text { adjusting for } \\
\text { confounding } \\
\text { factors } \\
\beta \text { (standard } \\
\text { error) } \\
\beta=-6.05 \\
(1.35) \mathrm{p}< \\
0.001 \\
\text { (Wasserman } \\
\text { et al., 2000) }\end{array}$ \\
\hline 2 & $\begin{array}{r}\text { PMID: } 16675439 \\
\text { DOI: } 10.1289 / \mathrm{ehp} .8552\end{array}$ & $\begin{array}{l}\text { Lourdes } \\
\text { Schnaas et } \\
\text { al, } 2005\end{array}$ & $\begin{array}{l}109 \\
\text { children }\end{array}$ & $\begin{array}{l}\text { Prospectiv } \\
\text { e cohort }\end{array}$ & $\begin{array}{c}\text { Pregnant women } \\
\text { were recruited at } 12 \\
\text { weeks of age, and }\end{array}$ & $\begin{array}{l}\text { Maternal IQ, } \\
\text { socioeconom } \\
\text { ic status, }\end{array}$ & $\begin{array}{l}\text { Lead } \\
\text { exposure, } \\
\text { especially at }\end{array}$ \\
\hline
\end{tabular}




$\quad$ Mexico
Reduced
Intellectual
Developmen
t in Children
with Prenatal
Lead
Exposure

DOI:

10.1016/j.neuro.2017.07.0

03 blood lead every 8 weeks until delivery. Maternal blood and umbilical cord blood during delivery were also taken.

Intelligence

measurement using the Spanish version of the Wechsler Fullscale IQ (FSIQ) Intelligence Scale for Children-Revised (WISC-R)

$\begin{aligned} & \text { Caroline M. } \\ & \text { Taylor et al, } \\ & 2017\end{aligned}$
children
England

Effects of low-level prenatal lead exposure on child IQ at 4 and 8 years in a UK birth cohort study

exposure is seen from

maternal blood lead

taken at 9-13 weeks'

$$
\text { gestation }
$$

Measurement of IQ at 4 years of age using the Wechsler Pre-

school and Primary

Scale of Intelligence

Revised UK edition

(WPPSI (Wechsler, 1990)
PMID: 30392942

DOI:

10.1016/j.envint.2018.10. 043

$\begin{array}{cc}\text { Mireille } & 609 \text { pairs } \\ \text { Desrochers- } & \text { of mothe } \\ \text { Couture et } & \text { and child } \\ \text { al, 2018, } & \\ \text { Canada } & \\ & \\ \text { Prenatal, } & \\ \text { concurrent, } & \\ \text { and sex- } & \end{array}$

measured maternal

le

level of

28 weeks

gestation, is

of caregivers with a

using the child's

HOME scale intellectual

development

with

possible

long-lasting

effects

$\beta(95 \% \mathrm{CI})$

$=-4.13(-$

$6.45 ;-1.81)$

p 0.001

(Schnaas et

al., 2006)

$\begin{array}{llll}\begin{array}{l}\text { Prospectiv } \\ \text { e cohort }\end{array} & \begin{array}{c}\text { Prenatal lead } \\ \text { exposure is seen from }\end{array} & \begin{array}{l}\text { The density } \\ \text { of residence, }\end{array} & \begin{array}{l}\text { The results } \\ \text { of maternal }\end{array}\end{array}$

smoking in

the first

trimester,

alcohol

blood lead

levels on

average 3.67

$\pm 1.46 \mathrm{~g} / \mathrm{dl}$

consumption

in the first

trimester,

maternal age Prenatal lead

at delivery, levels are

parity status, not

maternal associated

education, with IQ

gender, scores at

Measurement of IQ at child's age, either 4

age 8 using the weight at the

Wechsler Intelligence examination,

Scale for Children

$\mathrm{Hb}$, father's

WISC-III UK III

education,

economic

difficulties,

is there

substance

abuse, crime,

maternal

psychology

(anxiety,

depression,

suicidal

tendencies)

years or 8

years of age

4 years old

$\beta(95 \% \mathrm{CI})$

$=-0.18(-$

$0.63,0.28)$,

$\mathrm{p}=0.442$

8 years old

$\beta$ (95\% CI)

$-0.21(-0.69$,

$0.28), \mathrm{p}=$

0.397

(Taylor et

al., 2017)

Prenatal lead

Marital

status, parity

Mean

Prospectiv
e cohort

exposure was taken

from maternal blood

lead levels taken

during the first

ethnicity,

alcohol

trimester (6-13 weeks

gestation) and third

trimester (32-34

consumption,

and smoking

during

pregnancy, maternal

blood lead in

the first

trimester

was $0.62 \pm$

$1.6 \mathrm{~g} / \mathrm{dL}$, in

the second trimester 


specific
associations
between
blood lead
concentratio
ns and IQ in
preschool
Canadian
children

Cognitive function
examination using
Wechsler Preschool
and Primary Scale of
Intelligence-3rd
Edition, short version
(WPPSI-III;
Wechsler, 2002) in
the age range of 3-4
years

mercury

levels, birth

weight,

age, maternal $\quad 0.76 \pm 1.7$

BMI, $\quad \mathrm{g} / \mathrm{dL}$ and in

breastfeeding blood child

, parental $\quad 0.70 \pm \quad 1.7$

stress level $\quad \mathrm{g} / \mathrm{dL}$

There was

no

correlation

between the

WPPSI III

score and the

mother's

prenatal lead

concentratio

n.

$\beta(95 \% \mathrm{CI})$

$0.07 \quad(-0.14$

0.1) $\mathrm{p}=0.07$

(Desrochers-

Couture et

al., 2018)

In this systematic review, analysis was done by meta-analysis method using Review Manager 5.3 software. At the meta-analysis stage, it was carried out by summarizing and comparing the mean difference using the beta $(\beta)$ value and the confidence interval of lead levels compared with the results of IQ measurements with WISC. The primary instrument used to evaluate prenatal lead exposure on child development is the various versions of the Wechsler intelligence scale (WISC-III, WISC-IV, WISC-R, WISC-RM, WPPSI-III, WPPSI-R) for children aged between 5 years. and 15. This type of test is used in all articles evaluating the effect of this metallic element on the neurodevelopment of children. Here are the forest results plot in Figure 2.

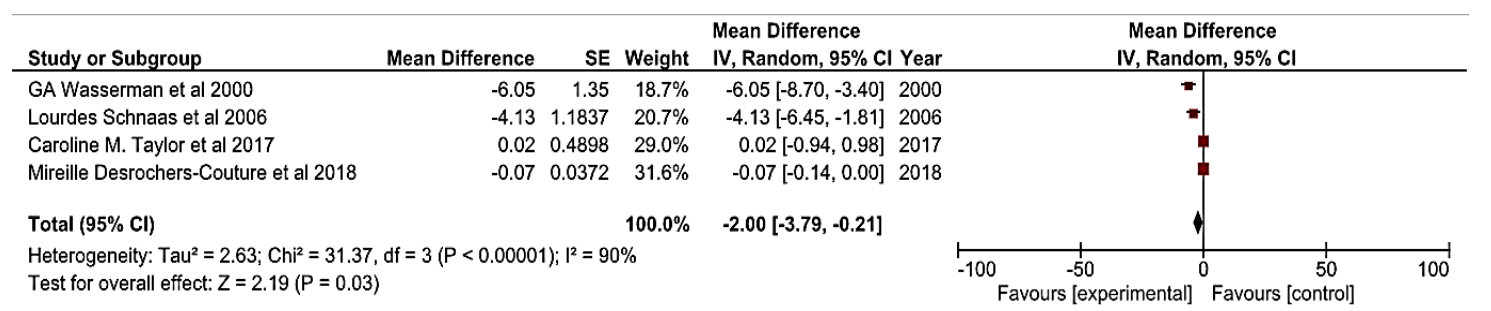

Fig. 2. Forest plot results of prenatal lead to cognitive (Full-scale IQ) Weschler Intelligence Scale

There are 4 journals reporting prenatal outcomes with cognitive development of -2.00 (95\% CI -3.79; $-0.21), p=0.03$. This indicates that the $\mathrm{p}$-value $<0.05$, means a significant correlation was found between prenatal lead and cognitive development. This study is heterogeneous because it can be seen in the results of $90 \% \mathrm{Tau}^{2}$ heterogeneity, so a random-effects model is used as the results merger. 


\section{Discussion}

Heavy metals globally are known to become major factors to cause birth abnormal. Some elements, such as lead $(\mathrm{Pb})$, mercury $(\mathrm{Hg})$, cadmium $(\mathrm{Cd})$, arsenic $(\mathrm{As})$, and chromium $(\mathrm{Cr})$, can move across the placental barrier and the blood-brain barrier, causing neurotoxicity in the fetus. These neurotoxicity effects can lead to congenital and neurological disabilities, developmental delays, behavioral disorders, and learning disabilities through several mechanisms..

There are 4 journals reporting prenatal outcomes with cognitive development of -2.00 (95\% CI -3.79; - 0.21 ), $\mathrm{p}=0.03$. This indicates that the $\mathrm{p}$-value $<0.05$, means significant correlation was found between prenatal lead and cognitive development. Mireille Desrochers-Couture study conducted on 609 mother-child pairs from the Maternal-Infant Research on Environmental Chemicals (MIREC) study with prenatal lead exposure taken from maternal blood samples during the first trimester of pregnancy (6-13 weeks gestation), during the third trimester (gestational age 32-34 weeks), and from umbilical cord blood at delivery, then in the child's blood at the age of 3-4 years. Cognitive examination using Wechsler Preschool and Primary Scale of Intelligence-3rd Edition, short version (WPPSI-III; Wechsler, 2002). From this study, it was found that the average maternal blood lead level in the first trimester was $0.62 \pm 1.6 \mathrm{~g} / \mathrm{dL}$, in the second trimester $0.59 \pm 1.7 \mathrm{~g} / \mathrm{dL}$, in umbilical cord blood $0.76 \pm 1.7 \mathrm{~g} / \mathrm{dL}$ and $0.70 \pm 1.7 \mathrm{~g} / \mathrm{dL}$ in children's blood. From the results of the cognitive examination using WPPSI-III, the average full-scale IQ result was $107.0 \pm 13.5$. Analysis between umbilical cord blood lead levels and full-scale IQ describing cognitive results showed that there was no relationship with 2.47 (95\% CI -0.30; $4.84), \mathrm{p}=0.11$, but when stratified by sex found a significant correlation between umbilical cord blood lead levels and the IQ performance component in boys with -3.28 (95\% CI -5.31; -1.18), $\mathrm{p}=0.03$ (DesrochersCouture et al., 2018).

Indeed, there is convergent evidence that men are more susceptible than women. Animal studies have reported a significant association between lead and male development, showing a decline in emotional and motor responses. A reasonable interpretation is the shielding effect of estrogen and the neurotransmitter's interaction. Female fetuses show a wider estrogen receptors distribution. Meanwhile, therefore the lower frequency of estrogen receptors in male fetuses may lead to a small protective effect (DiPietro and Voegtline, 2017; Jedrychowski et al., 2009; Kippler et al., 2013).

A study conducted by Lourdes Schnass et al. on 150 children in Mexico City, with prenatal lead exposure taken from maternal blood samples at 12-20 weeks gestation, then at 28-36 weeks, and from umbilical cord blood. Cognitive examination using the Spanish version of the Wechsler Intelligence Scale for ChildrenRevised (WISC-R). From the analysis using the relationship between prenatal lead levels and IQ, there was a significant relationship between 28 weeks gestational age lead levels and children's IQ at 7-year-old with -4.13 (95\% CI -6.45; -1.81), $\mathrm{p}=0.0006$ (Schnaas et al., 2006). It notified that the development of the fetal nervous system at 28 weeks is very different from the 12 weeks and the right time. The completion of neuroblast proliferation ended at 28 weeks. Besides, neuronal migration and aggregation resume from the first to the last trimester. Tract myelination in the developing human fetal brain only begins at 25 weeks of age. The lower cortical layers are not well-formed at 24 weeks of gestation, become complete at 28 weeks, and enter the postnatal form at 34 weeks of gestation (Herschkowitz, 1998).

Research conducted by Wasserman in 2 cities in Yugoslavia, namely Kosovo and Kosovska Mitrovica on 1502 pregnant women and followed up when the children were 3 years old (365 children), 4 years old (318 children), 5 years old ( 293 children), and the age of 7 years ( 289 children). Prenatal lead exposure is taken from 
the maternal blood during mid-pregnancy. Examination of cognitive development at the age of 3 and 4 years using the McCarthy Scales of Children's Abilities (MSCA), at the age of 5 and 7 years using the WPPSI-R (The Wechsler Preschool and Primary Scale of Intelligence Revised) and WISC-III (The Wechsler Intelligence). Scale for Children version III). From the analysis of the relationship among IQ, covariate, and prenatal lead, there was a significant relationship between prenatal lead levels and IQ at the age of 7 years with $-6.05(\mathrm{p}<$ 0.01 ), there was a decrease of 6.05 IQ nunbers in each $\log$ units of enhance in prenatal lead levels. It was hypothesized that the peak of susceptibility would correspond to a period of rapid early brain growth, considering that during this period there was a lot of synaptogenesis, arborization, and dendritic pruning (Wasserman et al., 2000).

Lead can cause toxicity to central nervous cells because it can cross the blood-brain barrier due to its capability as calcium ions $(\mathrm{Ca} 2+)$ substituent. Other evidence suggests the Ca-ATPase pump's role in transporting lead into the brain from capillary endothelial cells. The direct neurotoxic actions of this metal include excitotoxicity, apoptosis, effect on neurotransmitter storage and release, secondary carriers, cerebrovascular endothelial cells, oligodendroglia, and astroglia. Lead can also affect protein kinase C (PKC), playing a role in several essential cellular functions, such as proliferation, differentiation, and long-term potentiation, a form of neuronal plasticity involved in learning and memory. Chronic exposure to PKC in vivo causes a reduction in PKC expression in the hippocampus (Lidsky and Schneider, 2003).

Lead, at a minimum level of $10 \mathrm{mg} / \mathrm{dl}$ can decrease heme fabrication, consequently enhancing levels of $\delta$ aminolevulinic acid (ALA) precursor. ALA overcomes GABA-mediated neurotransmission by blocking its release and act as GABA receptors competitors. Lead can cause anemia, either by preventing heme construction or reducing iron absorption from the gastrointestinal tract. Critical iron deficiency and iron deficiency anemia are associated with impaired cognitive and neuropsychological development. At higher levels, lead causes acute encephalopathy, damage to the blood-brain barrier, brain edema, and brain ischemia (Lidsky and Schneider, 2003).

In this study, the characteristics of the literature by type of research are four prospective cohort studies for mercury. All subjects incorporated in the meta-analysis had distinguished methodological quality refers to the procedure defined in the study outline (STROBE). All studies have suitable designs and methods to achieve the research objectives and investigate confounding to avoid any bias which would affect the results. Therefore, we assure that the obtained results in this study are reliable. In this study, the Begg and Egger tests were applied to measuring publication bias and there was no publication bias in the meta-analyses $(p>0.05)$. The limitation of this study is that this study is the instrument for examining child development used is quite diverse and several journals do not include complete research results, namely beta values $(\beta)$ and confidence intervals. In this metaanalysis of all journals, the study design was a cohort, none was a randomized controlled trial (RCT).

\section{Conclusions}

As a result, there is a relationship between prenatal lead exposures on child development attributed by Wechsler Intelligence Scale for Children (WISC). These findings can be taken into consideration for conducting screening and early detection of child development according to schedule recommendations because each individual has different genetic variations. Further research especially by including extrinsic and intrinsic factors as confounding factors were required. 


\section{Acknowledgements}

The authors thank the Dr. Soetomo General Hospital, Surabaya Indonesia for providing the research facilities.

\section{References}

Caserta, D., Graziano, A., Monte, G. L., Bordi, G. and Moscarini, M., 2013. Heavy metals and placental fetalmaternal barrier: a mini-review on the major concerns. Eur Rev Med Pharmacol Sci 17, p. 2198-2206.

Desrochers-Couture, M., Oulhote, Y., Arbuckle, T. E., Fraser, W. D., Séguin, J. R., Ouellet, E., Forget-Dubois, N., Ayotte, P., Boivin, M. and Lanphear, B. P., 2018. Prenatal, concurrent, and sex-specific associations between blood lead concentrations and IQ in preschool Canadian children. Environment International 121, p. 1235-1242.

DiPietro, J. A. and Voegtline, K. M., 2017. The gestational foundation of sex differences in development and vulnerability. Neuroscience 342, p. 4-20.

Duffus, J. H., 2002. "Heavy metals" a meaningless term?(IUPAC Technical Report). Pure and Applied Chemistry 74, p. 793-807.

Herschkowitz, N., 1998. Brain development in the fetus, neonate and infant. Neonatology 54, p. 1-19.

Hsueh, Y.-M., Lee, C.-Y., Chien, S.-N., Chen, W.-J., Shiue, H.-S., Huang, S.-R., Lin, M.-I., Mu, S.-C. and Hsieh, R.-L., 2017. Association of blood heavy metals with developmental delays and health status in children. Scientific reports 7, p. 1-9.

Jedrychowski, W., Perera, F., Jankowski, J., Mrozek-Budzyn, D., Mroz, E., Flak, E., Edwards, S., Skarupa, A. and Lisowska-Miszczyk, I., 2009. Gender specific differences in neurodevelopmental effects of prenatal exposure to very low-lead levels: the prospective cohort study in three-year olds. Early human development 85 , p. 503-510.

Kippler, M., Engström, K., Mlakar, S. J., Bottai, M., Ahmed, S., Hossain, M. B., Raqib, R., Vahter, M. and Broberg, K., 2013. Sex-specific effects of early life cadmium exposure on DNA methylation and implications for birth weight. Epigenetics 8, p. 494-503.

Lidsky, T. I. and Schneider, J. S., 2003. Lead neurotoxicity in children: basic mechanisms and clinical correlates. Brain 126, p. 5-19.

Rehman, K., Fatima, F., Waheed, I. and Akash, M. S. H., 2018. Prevalence of exposure of heavy metals and their impact on health consequences. Journal of Cellular Biochemistry 119, p. 157-184.

Schnaas, L., Rothenberg, S. J., Flores, M.-F., Martinez, S., Hernandez, C., Osorio, E., Velasco, S. R. and Perroni, E., 2006. Reduced intellectual development in children with prenatal lead exposure. Environmental Health Perspectives 114, p. 791-797.

Shaikh, S. Z., Tejashree, D. and Ajit, D., 2021. Clinical utility of ultrasonography imaging in musculoskeletal conditions: A Systematic review and Meta-analysis. Journal of Medical Ultrasonics 48, p. 285-294. 
Sternberg, R. J., 2000. Handbook of intelligence, Cambridge University Press.

Taylor, C. M., Kordas, K., Golding, J. and Emond, A. M., 2017. Effects of low-level prenatal lead exposure on child IQ at 4 and 8 years in a UK birth cohort study. Neurotoxicology 62, p. 162-169.

Wasserman, G. A., Liu, X., Popovac, D., Factor-Litvak, P., Kline, J., Waternaux, C., LoIacono, N. and Graziano, J. H., 2000. The Yugoslavia Prospective Lead Study: contributions of prenatal and postnatal lead exposure to early intelligence. Neurotoxicology and Teratology 22, p. 811-818. 